\title{
Olgierd Górecki
}

University of Lodz, Poland

ORCID: 0000-0001-6852-3092

oGorecki@wpia.uni.lodz.pl

\section{Whom Does Law Serve? \\ The Libertarian Albert Jay Nock's Concept}

Komu służy prawo? Libertariańska koncepcja Alberta Jaya Nocka

\begin{abstract}
Albert Jay Nock (1870-1945) was a prominent opinion journalist of the first half of the $20^{\text {th }}$ century, considered a representative of the first generation of libertarianism. The article is aimed at finding an answer to the question: Whom - according to Nock - does law serve? A key element of the problem is the internal dichotomy of the concept of law, which not only can be seen through the prism of the positivist-legal paradigm, but also constitutes the pillar of the jusnaturalistic concept. To properly arrange the object of study, the thesis was used according to which in Nock's doctrine the existence of radically different assessment of the nature of man and his individual goals from the nature of the functioning of the State allows us to demonstrate the dichotomy of two opposing legal orders that serve the welfare of different entities (the individual and the State). To systematize the argument, the concept of the individual and his relations with the State was first presented, and then the dichotomy of the government and the State was discussed, which ultimately finally allowed to analyze the relationship between natural law and positive law.
\end{abstract} concept

Keywords: natural law; positive law; libertarianism; positivist-legal paradigm; jusnaturalistic

CORRESPONDENCE ADDRESS: Olgierd Górecki, PhD, Assistant Professor, University of Lodz, Faculty of Law and Administration, Kopcinskiego 8/12, 90-232 Lodz, Poland. 
The general upshot of my observations, however, was to show me that whether in the hands of Liberal or Conservative, Republican or Democrat, and whether under nominal constitutionalism, republicanism or autocracy, the mechanism of the State would work freely and naturally in but one direction, namely, against the general welfare of the people. ${ }^{1}$

\section{INTRODUCTION}

Albert Jay Nock (1870-1945) was an outstanding opinion journalist of the first half of the $20^{\text {th }}$ century, who should be considered as the first generation of libertarianism. ${ }^{2}$ He did not write complex and comprehensive philosophical treatises, but as a journalist and columnist of such journals as, i.a., "American Magazine", "Atlantic Monthly", "Harper's", "Scribner's" and "American Mercury", and as a co-editor of "The Freeman", he commented on political, cultural and social events on an ongoing basis, referring to historical events (most often ancient Greece and Rome and the history of the USA) and drawing accurate conclusions of a comparative nature. Assessing the then-American present, he used to refer to the situation in various European countries in which he had the opportunity to stay for several years. Finally, it should be noted that his arguments often contained references to numerous political and legal doctrines and philosophical systems. An attentive reader will find in his works references to, i.a., Plato, Aristotle, Plutarch, Smith, Hobbes, Filmer, Locke, Rousseau, Hegel, Fichte, Kant, Tocqueville, Bentham, Mill, Spencer, Marx, Lenin and of course all the so-called Fathers of the US Constitution. At present, only one treatise by Nock can be read in Polish, the one considered the most important, entitled Our Enemy, the State. It is worth noting, however, that he

1 A.J. Nock, Anarchist's Progress, [in:] idem, On Doing the Right Thing and Other Essays, New York 1928, p. 148.

${ }^{2}$ In the literature on the subject one can also find a position that classifies the Nock's views as anarcho-individualism (more detail in M. Wreszin, Albert Jay Nock and the Anarchist Elitist Tradition in Amerika, "American Quarterly" 1969, vol. 21(2/1), pp. 165-189), or even anarcho-capitalism (J. Bartyzel, Geneza i próba systematyki głównych nurtów libertarianizmu, [in:] Libertarianizm. Teoria, praktyka, interpretacje, eds. W. Bulira, W. Gogłoza, Lublin 2010, pp. 27-28; R. Wojtyszyn, Anty-lewiatan. Doktryna polityczna i prawna Murraya Newtona Rothbarda, Wrocław 2017, pp. 113-114). David Boaz considered Nock as one the last classical liberals, from whom the current libertarian movement originates. See D. Boaz, Libertarianizm, Poznań 2005, pp. 77-78. 
was the author of twelve other books, ${ }^{3}$ six introductions to books by other authors, ${ }^{4}$ and after his death, another seven works were published, constituting collections of his most widely read essays and op-ed pieces. ${ }^{5}$

As regards the sources of inspiration for Nock's political thought, it should be noted that its originality lies in the eclectic combination of the concepts proposed by several authors into one innovative and conceptually coherent doctrinal whole. In my opinion, Nock borrowed: 1) from Thomas Pain - the separation of government from the State (although he radically modified it); 2) from Herbert Spencer - the vision of evolutionary social processes, along with a criticism of extensive legislation that disturbs natural social harmony; 3) from Ludwik Gumplowicz and Franz Oppenheimer - the theory of conquest as a genesis explaining the emergence, development and functioning of the State; 4) from José Ortega y Gasset - the vision of social masses controlled by the State; 5) from Ralph Adams Cram - the elitist perspective on members of society, in which each member can be trained in some profession or occupation, but where it is impossible to educate everyone to be sensitive aesthetes and reflective intellectuals. Certainly, Nock's personality and views were also influenced by the works of Francis Rabelais, Henry George and Artemus Ward (real name Karol Farrar Browne), to whom he also often referred. ${ }^{6}$

${ }^{3}$ Nock's works published before his death (in alphabetical order): A Journey Into Rabelais's France, New York 1934; A Journal of These Days: June 1932 - December 1933, New York 1934; Francis Rabelais: The Man and His Work, New York 1929; Free Speech and Plain Language, New York (1937) 1968; Henry George, New York 1939; Jefferson, New York 1926; Memoirs of Superfluous Man, New York (1943) 2007; On Doing the Right Thing, and Other Essays, New York 1928; Our Enemy, The State, New York 1935; The Book of Journeyman: Essays from the New Freeman, New York (1930) 1967; The Myth of Guilty Nation, Auburn (1922) 2011; The Theory of Education in United States, New York 1932; World Scouts, Boston 1912. He was also the co-author of The Freeman Book (ed. B.W. Huebsch, New York 1924), an extensive book containing essays selected by B.W. Huebsch, originally published in "The Freeman" in 1920-1924.

${ }^{4}$ Introductions by Nock to the books: H.S. Haskins, Meditations in Wall Street, New York 1940; F. Neilson, How Diplomats Make War, New York 1915; F. Rabelais, The Work of Francis Rabelais, eds. A.J. Nock, C.R. Wilson, vol. 1-2, New York 1931; H. Spencer, Man Versus the State, Indianapolis (1940) 1981; B. Whitlock, Forty Years of It, New York 1914; A. Ward, The Selected Works of Artemus Ward, New York 1924.

${ }^{5}$ Nock's works published after his death: Journal of Forgotten Days. May 1934 - October 1935, Hinsdale 1948; Letters from Albert Jay Nock 1924-1945: to Edmund C. Evans, Mrs. Edmund C. Evans and Ellen Winsor, Caldwell 1948; Informed Common Sense: The Journals of Albert Jay Nock, Baltimore 2013; Selected Letters of Albert Jay Nock, ed. F.J. Nock, Caldwell 1962; Snoring as a Fine Art and Twelve Other Essays, Rindge 1958; The Disadvantages of Being Educated and Other Essays, Tampa 1996; The State of The Union. Essays in Social Criticism, Indianapolis 1991. Nockian Society issued also a collection of quotes from Nock, edited by Robert M. Thornton and with an introduction by Jacques Barzun. See A.J. Nock, Cogitations from Albert Jay Nock, ed. R.M. Thorton, introduction J. Barzun, New York 1985.

${ }^{6}$ More on the sources of Nock's inspiration: M. Wreszin, The Superfluous Anarchist. Albert Jay Nock, Providence 1972, pp. 127-148. 
The aim of this article is to answer the question asked in the title: Whom does law serve? The search focuses on the analysis of the political and legal doctrine proposed by Nock. The key element in the problem is the internal dichotomy of the concept of law, which not only can be seen through the prism of the positivist-legal paradigm, but also constitutes the pillar of the jusnaturalistic concept. To properly arrange the object of study, the thesis was used according o which in Nock's doctrine, the existence of radically different assessment of the nature of man and his individual goals from the nature of the functioning of the State allows us to demonstrate the dichotomy of two opposing legal orders that serve the welfare of different entities (the individual and the State). To systematize the argument, the concept of the individual and his relations with the State, and then the dichotomy of the government and the State, which ultimately finally allowed to analyze the relationship between natural law and positive law.

\section{CONCEPT OF THE INDIVIDUAL AND HIS RELATIONS WITH THE STATE}

In the article Life Liberty and ..., originally published in the New York periodical "Scribener's Magazine" in March 1935, ${ }^{7}$ Nock outlined the duality of the relationship between the individual and the State. On the one hand, this is a relationship that can be described as natural-law one, characterized by the priority of the individual's good over the State. They are opposed to empirically perceived relationships which reveal the totally privileged position of the State. As the basis for the former, he adopted the formula of natural human rights put forward by John Locke (the right to life, freedom and property), ${ }^{8}$ which was later revised by Thomas Jefferson in the Declaration of Independence of the United States as a more inclusive formula: the right to life, freedom and the pursuit of happiness. ${ }^{9}$ According to Nock, Jefferson made this revolutionary change in order to broaden the scope of protection of the inviolable sphere of every human being, because the phrase "pursuit of happiness" is semantically broader than merely securing private property. ${ }^{10}$ Such a defined normative status of the individual determines the existence of the State limited only to a negative scope of activities, which consists solely in protecting a person from any violation of his natural right by other people. As Nock described it: "The State's whole duty is, first, to abstain entirely from any positive regulation of the individual's conduct; and, second, to make justice easily and costlessly accessible

\footnotetext{
7 A.J. Nock, Life liberty and..., [in:] idem, The Disadvantages..., pp. 29-41.

8 J. Locke, Dwa traktaty o rzadzie, Warszawa 2015, p. 329; Z. Rau, Wstęp, [in:] J. Locke, op. cit., p. 53.

9 T. Jefferson, Political Writings, eds. J. Appleby, T. Ball, Cambridge 1999, p. 97.

${ }^{10}$ A.J. Nock, Life liberty..., p. 29.
} 
to every applicant. [...] Its legitimate concern is with but two matters: first, freedom; second, justice". ${ }^{11}$

Taking the natural-law perspective as an a priori axiom, Nock deliberated why, during his numerous travels around various European countries and his home country as well, he observed unhappy people so often. He considered the reason for this State of affairs to be the departure of the State from this Jefferson's formula, through its numerous and progressive interferences in the broadly understood sphere of individual's negative freedom. He wrote, almost enumerating in detail, that the authorities often limit the people in what they can trade, where they can move, where they can live, what they can produce, what they can eat, what they can read, and even what the model of discipline and upbringing in the family should be. These restrictions, directly aimed at the individual, are further supplemented by an expansion of the functions and structure of the State apparatus, which is no longer limited to administering justice and providing security, but has also become, among other things: an operator of railways and water transport; a builder of ships, houses, clothes, shoes and weapons; a wholesaler and retailer of tobacco products; a banker and usurer; a supplier of newspapers, a radio broadcaster; an owner of aviation companies, post offices, pawn shops, etc. The State has also invaded the field of charity, generously distributing public money in the form of various allowances or by organizing work for the unemployed. It gave itself the titles of chief educator, pharmacist, chemist, farmer and sanitary inspector. ${ }^{12}$ Nock emphasized that all the above-mentioned elaborate forms of State activity were financed with funds from the people and therefore not only infringe upon the positive freedom of man to take action himself, but also interfere with the property of the individual (negative freedom in its broad sense). ${ }^{13}$ The only area in which a decrease in State interference can be observed is the freedom of religion and choice of religion.

Additionally, Nock pointed out that the originally determined tasks of the State, concerning the provision of security and justice, are in fact carried out in an expensive, slow and ineffective way and lead to the spread of corruption. He enriched his observations - drawn both from the current political situation and historical events - by referring to Spencer's considerations contained in the essay The New Toryism (from his most famous book entitled The Man versus the State), which were in this respect almost identical to his own. ${ }^{14}$ Nock expressed the belief that based on these differences existing between the desired and the actual scope of

11 Ibidem, p. 31.

12 Ibidem, p. 33.

13 These Nock's views were certainly inspired by Spencer's works, in which similar criticism of extensive state function, especially that of social welfare nature, constituted a regular subject of socio-political reflection. For more detail, see O. Górecki, Obrona państwa ograniczonego. Polityczno-prawna doktryna Herberta Spencera, Kraków 2013, pp. 162-166.

${ }^{14}$ H. Spencer, Jednostka wobec państwa, Warszawa 2001, pp. 19-44. 
State's operation (in the countries of Western civilization of the 1910s), a complete reversal of the hierarchy of natural values took place. For it is not the case, but it should be, that the State exists to protect the individual, but on the contrary, it is the individual who lives in conditions that force him to be subservient to the State. As he wrote: "A man is in slavery when all his rights lie at the arbitrary discretion of some agency other than himself; when his life, liberty, property and the whole direction of his activities are liable to arbitrary and irresponsible confiscation at any time - and his appeared to be the exact relations that I saw obtaining between the individual and the state". ${ }^{15}$ For slavery perceived this way, it does not matter who exploits the individual (whether another individual or the State), or how this asymmetric relationship originated (whether voluntarily or by coercion).

Nock then pointed out that two dichotomously different political theories can be distinguished. He called the first of them "the theory of the Declaration" - it is a concept expressed in the already mentioned Declaration of Independence of the United States, based on the natural-law, ontological axiom that man, by virtue of being a human ("in virtue of his humanity"), is born with certain rights which: first, do not come from the State, and second, cannot be violated by anyone, and third, which are inalienable. ${ }^{16}$ Therefore, according to this theory, this state exists for the good of people. The second concept mentioned by Nock is the so-called "absolutist theory of politics", ${ }^{17}$ which assumes that it is people, having no natural rights, who live for the omnipotent state that defines their normative status in a completely arbitrary and conventional manner. Hence, in such a state, human rights are completely dependent on the will of those in power, who can freely grant them, modify them temporarily, and take them away by virtue of unlimited statutory law. As an example of such a theory, he quoted Benito Mussolini's famous line: "All within the state, nothing outside the state, nothing against the state" ${ }^{18}$ For Nock, the "absolutist theory of politics" found its embodiment in socialism, Bolshevism, communism, fascism, Marxism and Nazism. It is also worth adding that in his other publications, he also included the United States in this catalogue after the reforms made by Franklin Delano Roosevelt. ${ }^{19}$ An important feature of the absolutist theory is also its assumption that the state is an objectively existing organism, independent of its constituent individuals. ${ }^{20}$ Nock, however, rejected this idea, sarcastically

15 A.J. Nock, Life liberty..., p. 36.

16 Ibidem, p. 36.

${ }_{17}$ Also referred to in his other publications as, alternatively, "collectivist theory", "statist theory", theory of "statism", or simply the theory of an absolute state.

${ }_{18}$ In the Italian original: "Tutto nello Stato, niente al di fuori dello Stato, nulla contro lo Stato". For more detail, see B. Mussolini, Doktryna faszyzmu, Lwów 1935, pp. 21-22.

19 A.J. Nock, Our Enemy..., p. 14.

${ }^{20}$ He negated Thomas Carlyle's statement that the State is an essential and necessary combination of many individuals into a new collective entity. See idem, Life liberty..., p. 37. 
pointing out that if, hypothetically, all Germans died overnight, the next day the absolutist Nazi state would only be a poetic expression. This shows the paradigm of methodological individualism, which characterized his entire political reflection. ${ }^{21}$

The essence of Nock's argument in the article Life liberty and... is an attempt to find an answer to the question: Under what conditions can man most effectively pursue happiness, which - as already pointed out - belongs to Jefferson's triad of natural rights? Nock referred to in that article several alternative definitions of happiness, but stipulated that he was not interested in constructing some sublime scientific formula, but referred to the intuitively and universally accepted meaning of the concept. As he wrote: "By happiness I mean happiness. [... I I refer to a stable condition of mind and spirit [...] a condition so easily recognized and so well understood that I do not need to waste space on trying to define it". ${ }^{22}$ Nock then supplemented the question asked, by questioning whether it is at all possible for any human being to successfully pursue happiness while living in a state with an absolute regime. Nock, in order to answer this question, in a manner characteristic of his writing style, used an example taken from the pages of Charles Dickens' first novel The Pickwick Papers. ${ }^{23} \mathrm{He}$ recalled the scene in which the main character Samuel Pickwick, together with a young medical student, Jack Hopkins, evaluate the success of a surgical procedure that has just been performed. For the student, the procedure is successful if carried out correctly. For Mr. Pickwick, on the other hand, the success of the procedure is proved by the improvement in the patient's health. Nock, referring to these two different positions, observed that during his numerous travels around Europe, he had repeatedly noticed manifestations of Hopkins-like thinking in the policies of various countries. This means that lawmakers, in order to make the "Age of Plenty" materialized and create a perfect social order, are interfering more and more at various levels of activity, replacing the spontaneous and natural balance of social relations with a progressive confiscation of freedom, centrally controlled by bureaucratic governance. On the other hand, Nock pointed out that he himself sympathized more with Pickwick's position, i.e. that he was more interested in what will be the condition of people subjected to the political therapy of the absolute State, than in the objectives that this State sets for itself in its internal policy. Continuing the considerations, he astutely stated: "Let us make an extreme hypothesis. Let us suppose that instead of being slow, extravagant, inefficient, wasteful, unadaptive, stupid, and at least by tendency corrupt, the state changes its character entirely, and becomes infinitely wise, good, disinterested, efficient, so that any may run to it with any little two-penny problem and have it solved for him at once in the wisest and best way possible. Suppose the state close-herds the individual so far as to forestall every conceivable consequence

\footnotetext{
21 Idem, Cogitations..., p. 48.

22 Idem, Life liberty..., p. 38.

23 Also known as The Posthumous Papers of the Pickwick Club.
} 
of his bad judgement, weakness, incompetence; suppose it confiscates all his energy and resources and employs them much more advantageously all round than he can employ them if left to himself. My question still remains - what sort of person is the individual likely to become under those circumstances?". ${ }^{24}$

Importantly, Nock did not explicitly answer the question because he preferred to adhere to his own beliefs that he would never force or incite anyone to do anything. He was therefore a man close to the Socratic ideal of acquiring knowledge by debunking false opinions and directing the interlocutor - in this case, the reader - to seek the truth on his own. As a side note, this has grounds in Nock's life maxim that the only thing that can be done to improve society is to give to it one improved individual (that is, himself). ${ }^{25}$

However, returning to the interpretation of the quote mentioned above, it should be noted that the American columnist was motivated by the intention to stir up the reader's imagination and direct him to self-reflective deliberations: Is it possible for man to achieve happiness when someone other than himself decides what is this happiness and how one can pursue it? How much human happiness is conditioned by the character of man, his inviolable integrity of personality, cultivation of self-respect (i.e., a sense of dignity), and preservation of the independence of his own judgments? How much individual pursuit of happiness can be reconciled with membership of a society that serves an interventionist state? And finally, can a person who has an informal but real status as a slave of the state be happy at all? ${ }^{26}$ Nock deliberately gave no answer to these questions. However, examining his writings, one can only draw one conclusion which is consistent with his views, expressed in the belief that only a free individual, i.e. not limited by the state in its choices and actions, is able to achieve individual happiness, no matter what form it takes.

\section{DICHOTOMY BETWEEN GOVERNMENT AND THE STATE}

Nock argued that there were only two ways people can meet their needs. The first is the economic measures involving production and trade, and the second is political measures, which involve the appropriation of goods produced by others without any compensation being granted. ${ }^{27}$ The distinction between these two

${ }^{24}$ A.J. Nock, Life liberty..., p. 39.

${ }^{25}$ R.M. Thornton, Introduction: A Stroll With Albert Jay Nock, [in:] A.J. Nock, The Disadvantages..., p. II.

26 A.J. Nock, Life liberty..., pp. 40-41.

27 Murray Newton Rothbard, referring to this Nock's concept, distinguished "social power" boiling down to power over nature and "state power" tantamount to power over man. See M.N. Rothbard, Egalitaryzm jako bunt przeciw ludzkiej naturze, Warszawa 2009, pp. 132-133; idem, Etyka wolności, Warszawa 2010, p. 301. 
methods is the basis for Nock's division into two distinct types of political organization, which, despite a fundamental generic difference, are called the government. The divergences between them relate mainly to the genesis, purpose of existence, method of performance of functions, scope of influence or source of legitimacy. As Nock wrote: "Hence it is by no means either an arbitrary or academic proceeding to give the one type the name of government, and to call the second type simply the state". ${ }^{28}$ According to the American columnist, "government" is a social institution whose sole purpose is to safeguard the natural rights of the individual, that is, as already stated, to ensure his freedom and security. The "government" thus perceived is a natural entity characterized by legitimacy derived from the consent of the ruled. The efficiency of the government is manifested in the process of simple and free administration of justice. Thus, the whole range of government activity amounting to acting as a neutral arbitrator is limited only to the negative impact.

The opposite of "government" is the "State". Nock defined it as a centralized and bureaucratic organization of political resources, which is the main distributor of economic advantage and the supreme arbiter of their exploitation, with its own military apparatus and police force. ${ }^{29}$ As he wrote, it is "the State's progressive confiscations of social power" seeking to establish a monopoly of economic rent. ${ }^{30}$ Therefore, the real purpose of the existence of public power in the State is to enlarge the scope of its influence, because in reality it serves primarily for its own welfare. ${ }^{31}$ In assessing the functioning of the State, he noted that when it pursues social objectives it acts extremely inefficiently and slowly, whereas when it seeks to satisfy its own needs, such as when collecting taxes, the public authorities are able to act efficiently, consistently and relentlessly. Nock stated that a feature of such a system is an increase in the centralization and bureaucracy of state institutions, with a simultaneous decrease in the freedom of all individuals who do not directly benefit from participation in public power. One can therefore see a progressive loss of social power in favour of an increase in the powers of the State. In contrast to "government", the legitimacy of power in the "State" comes from the conquest and indoctrination of society members. Therefore, Nock argued that from its ability to legitimately use coercive means against its citizens, the obvious conclusion is that it is in fact a monopolist in terms of commission of crimes. ${ }^{32}$

28 A.J. Nock, Our Enemy..., p. 22.

${ }^{29}$ I used this Nock's definition of the State in one of my articles. See O. Górecki, Rekonstrukcja historycznych podstaw i ideologicznej ciaglości wspótczesnego libertarianizmu, [in:] Tendencje rozwojowe myśli politycznej i prawnej, eds. M. Maciejewski, M. Marszał, M. Sadowski, Wrocław 2014, p. 338.

30 A.J. Nock, Our Enemy..., p. 51.

31 M.N. Rothbard, Manifest libertariański, Warszawa 2014, p. 55.

${ }^{32}$ M. Modrzejewska, Libertariańskie koncepcje jednostki i państwa we wspótczesnej amerykańskiej myśli politycznej, Kraków 2010, p. 74; Z. Rau, Liberalizm. Zarys myśli politycznej XIX i XX wieku, Warszawa 2000, p. 175. 
It should also be noted that Nock, employing the historical method in the study of the institution of the State, held, following the prominent $19^{\text {th }}$-century sociologists such as Ludwik Gumplowicz (1838-1909) and Franz Oppenheimer (1864-1943), that the only reason why the State was created is conquest and confiscation. ${ }^{33}$ Hence the state is always class-based, in the broad - not Marxist - sense of the word.

\section{NATURAL LAW AND POSITIVE LAW}

It is a truism that the concept of natural law is an ambiguous term in the context of research in the field of political and legal doctrines. ${ }^{34}$ In the article The God's Lookout, Nock presented the view that what people call natural law is nothing more than a registration of experience. ${ }^{35}$ As he wrote: "If human experience of some natural phenomenon has been uniform, it sets up a correspondingly strong expectation that subsequent experience will be likewise uniform, and we call the formula for that experience a natural law, even though the term be a misnomer, strictly speaking, for we actually know of no 'law' anywhere in the universe that guarantees the fulfillment of our expectation". ${ }^{36}$ This quote suggests that for Nock the concept of natural law was not limited only to rational cognition by man of his own nature, which would allow him to put forward specific postulates to lawmakers, but also related to the broadly understood universal laws since, as he himself pointed out, natural law is also the laws of optics and gravity. Therefore, it is reasonable to say that for Nock the concept of natural law goes beyond the very concept of human nature and also includes all laws that can be defined by the broader category of the law of nature. ${ }^{37}$ It should be stressed, however, that there is no direct use of any references to metaphysical entities that would legitimize the existence of the said laws of nature and the natural rights of man deriving from them.

I have tried to present the existence in Nock's socio-political thought of a permanent, intellectual tension between the abstract theoretical vision of an individual

${ }^{33}$ M.R. Crunden, The Mind and Art of Albert Jay Nock, Chicago 1964, pp. 60-61.

34 For more detail on natural law in political and legal doctrines, see L. Strauss, Prawo naturalne w świetle historii, Warszawa 1969; R. Tokarczyk, Klasycy praw natury, Lublin 2009; J. Hervada, Historia prawa naturalnego, Kraków 2013; Prawo natury w doktrynach polityczno-prawnych Europy, ed. M. Zmierczak, Poznań 2006; M. Maciejewski, Doktrynalne ujęcie prawo naturalne-prawo stanowione od starożytności do czasów oświecenia, "Krakowskie Studia z Historii Państwa i Prawa" 2015, vol. 8(2), pp. 107-132; idem, Odniesienia między prawem naturalnym i prawem stanowionym $w$ wybranych doktrynach filozoficznych, politycznych i prawnych, [in:] Pozytywizm prawniczy i szkota prawa natury - tradycje sporu i jego wspótczesne implikacje, eds. P. Kaczmarek, Ł. Machaj, Wrocław 2010.

35 A.J. Nock, The God's Lookout, [in:] idem, Free Speech ..., p. 307.

${ }^{36}$ Ibidem, pp. 307-308.

${ }^{37}$ M. Szyszkowska, Dociekania nad prawem natury, czyli o potrzebach człowieka, Warszawa 1972, p. 30. 
who has inviolable, negative natural powers to life, freedom and happiness, and his pejorative assessment of the concept of the State that has emerged as a result of conquest and violence (so-called exogenous genesis ${ }^{38}$ ) and exists solely to exploit and subjugate its citizens. Such a perspective begs a reasonable association with the concept of an "oble savage" - known from Rousseau's works - who degenerates morally as a result of the conclusion of increasingly extensive social bonds. ${ }^{39}$ However, Nock was not enthusiastic about any concept of social contract, claiming that these had no historical value..$^{40}$

Based on the analysis of fundamental assumptions of the $19^{\text {th }}$-century thinker, it is necessary to reconstruct his views on what is law and whom it serves. First of all, it should be pointed out that Nock used the concept of law in two fundamentally different meanings. This is due to the fact that it referred to two concurrent normative legal orders. The first is natural law - empirically recognizable by man. It is absolute and any action against it entails inevitable consequences. That is why for Nock "Any contravention of natural law, any tampering with the natural order of things, must have its consequences, and the only recourse for escaping them is such as entails worse consequences. Nature recks nothing of intentions, good or bad; the one thing she will not tolerate is disorder, and she is very particular about getting her full pay for any attempt to create disorder" ${ }^{41}$ It should be stressed that the law of nature is unchangeable and universal for the whole world, and thus for all people. It is therefore significant that Nock referred to natural law as justice, not law.

The second legal order is the law created by the entity (class) which exercises power in the State. Regardless of the political form of the State, the sole purpose of the existence of positive law is to maintain public authority as effectively as possible, and thus to monopolize the use of political means allowing the appropriation of goods produced by other people, without having to compensate for the losses incurred. Nock argued that "the State is by its nature concerned with the administration of law - law, which the State itself manufactures for the service of its own primary ends". ${ }^{42}$ The scope of positive law regulation depends on the dynamics of social and political relations taking place in each particular country at a certain time.

Both legal orders exist concurrently and the relationship between them has a decisive impact on the level of existence of people and the scope of functioning of the State. If, for the sake of clarity of academic deliberation, two ideal models were to be devised, corresponding to the primacy of natural law over positive law and the other way round, the following conclusions could then be drawn. If the

\footnotetext{
38 T. Teluk, Koncepcje państwa we wspótczesnym libertarianizmie, Warszawa 2006, p. 88.

39 In more detail: J.-J. Rousseau, Umowa społeczna, Kęty 2007.

${ }^{40}$ A.J. Nock, Our Enemy ..., p. 23.

${ }^{41}$ Ibidem, p. 92.

${ }^{42}$ Ibidem, p. 92.
} 
rules of natural law are respected, then there is a limited State, referred to by Nock in his nomenclature as a "government": "[...] under a regime of natural order, that is to say under government, which makes no positive interventions whatever on the individual, but only negative interventions in behalf of simple justice - not law, but justice - misuses of social power would be effectively corrected". ${ }^{43}$ It is idealized - although not entirely utopian ${ }^{44}$ - social system allowing every man to enjoy full freedom, which is a sine qua non condition for achieving happiness.

The second model would serve to show the domination of the positive law system that completely disregards the principles of natural law. Then we would be dealing with a highly centralized, collectivist and bureaucratic state that directly interferes on all levels of social and economic activity, simultaneously dictating certain axiological norms and verifying compliance with them. However, it would be a symbolic state standing on the abyss of its further existence, for - as Nock wrote - "The course of all these civilizations was the same. Conquest, confiscation, the erection of the State; then the sequences which we have traced in the course of our own civilization; then the shock of some irruption which the social structure was too far weakened to resist, and from which it was left too disorganized to recover". ${ }^{45}$ However, this question goes beyond the scope of this article, but one can put it simply that for Nock the progressive development of an increasingly complex State must ultimately end in its demise.

Summing up, the following relationship can be derived from the above reasoning - the decrease in adhering to the principles of natural law is a determinant of the degree of absolutization of the state and like, metaphorically speaking, fine sand in the hourglass that slowly counts the time of the existence of the state, indicates when the mortal god - Leviathan - will die struck by the burden of original sin, condemning him to destruction from the very moment of his conception.

\section{CONCLUSIONS}

When trying to give a final answer to the question specified in the title of the article-Whom does law serve? - it turns out that there is no unambiguous answer. Everything depends on which kind of law is being referred to. Natural law always serves every human being regardless of his or her social status. Positive law, on the other hand, expresses the interests of those in power. However, an inquisitive researcher may go further in analysis and notice another important conclusion,

43 Ibidem, p. 93.

${ }^{44}$ He presented various native American tribes as examples of such a community. In more detail: idem, Jefferson ..., p. 112; idem, Our Enemy ..., pp. 21-22.

${ }^{45}$ Idem, Our Enemy..., p. 94. 
which was not expressed clearly enough by the American writer himself. Well, if Nock treated the law of nature exceptionally broadly, including in it, e.g., the above-mentioned laws of physics, it should be noted that the laws of sociology, which invoked by referring to the views of Spencer, Gumplowicz and Oppenheimer considering them certain and scientific, should also be included in the laws of nature in this sense. This in turn leads to the conclusion that this pejoratively perceived character of positive law is in fact a natural consequence of the empirically perceived social nature of man. Therefore, as the final conclusion, it should be noted that Nock's socio-political doctrine takes a fatalistic form. Modern man will never find full freedom and enjoy full happiness because he is condemned to live in an inherently anti-social state.

\section{REFERENCES}

Bartyzel J., Geneza i próba systematyki głównych nurtów libertarianizmu, [in:] Libertarianizm. Teoria, praktyka, interpretacje, eds. W. Bulira, W. Gogłoza, Lublin 2010.

Boaz D., Libertarianizm, Poznań 2005.

Crunden M.R., The Mind and Art of Albert Jay Nock, Chicago 1964.

Górecki O., Obrona państwa ograniczonego. Polityczno-prawna doktryna Herberta Spencera, Kraków 2013.

Górecki O., Rekonstrukcja historycznych podstaw i ideologicznej ciagłości współczesnego libertarianizmu, [in:] Tendencje rozwojowe myśli politycznej i prawnej, eds. M. Maciejewski, M. Marszał, M. Sadowski, Wrocław 2014.

Hervada J., Historia prawa naturalnego, Kraków 2013.

Jefferson T., Political Writings, eds. J. Appleby, T. Ball, Cambridge 1999.

Locke J., Dwa traktaty o rzadzie, Warszawa 2015.

Maciejewski M., Doktrynalne ujęcie prawo naturalne - prawo stanowione od starożytności do czasów oświecenia, "Krakowskie Studia z Historii Państwa i Prawa" 2015, vol. 8(2).

Maciejewski M., Odniesienia między prawem naturalnym i prawem stanowionym w wybranych doktrynach filozoficznych, politycznych i prawnych, [in:] Pozytywizm prawniczy i szkoła prawa natury - tradycje sporu i jego wspótczesne implikacje, eds. P. Kaczmarek, Ł. Machaj, Wrocław 2010.

Modrzejewska M., Libertariańskie koncepcje jednostki i państwa we wspótczesnej amerykańskiej myśli politycznej, Kraków 2010.

Mussolini B., Doktryna faszyzmu, Lwów 1935.

Nock A.J., A Journey Into Rabelais's France, New York 1934.

Nock A.J., A Journal of These Days: June 1932 - December 1933, New York 1934.

Nock A.J., Anarchist's Progress, [in:] idem, On Doing the Right Thing and Other Essays, New York 1928.

Nock A.J., Cogitations from Albert Jay Nock, ed. R.M. Thorton, introduction J. Barzun, New York 1985.

Nock A.J., Francis Rabelais: The Man and His Work, New York 1929.

Nock A.J., Free Speech and Plain Language, New York (1937) 1968.

Nock A.J., Henry George, New York 1939.

Nock A.J., Informed Common Sense: The Journals of Albert Jay Nock, Baltimore 2013.

Nock A.J., Introduction, [in:] H.S. Haskins, Meditations in Wall Street, New York 1940. 
Nock A.J., Introduction, [in:] F. Neilson, How Diplomats Make War, New York 1915.

Nock A.J., Introduction, [in:] H. Spencer, Man Versus the State, Indianapolis (1940) 1981.

Nock A.J., Introduction, [in:] A. Ward, The Selected Works of Artemus Ward, New York 1924.

Nock A.J., Introduction, [in:] B. Whitlock, Forty Years of It, New York 1914.

Nock A.J., Jefferson, New York 1926.

Nock A.J., Journal of Forgotten Days. May 1934 - October 1935, Hinsdale 1948.

Nock A.J., Letters from Albert Jay Nock 1924-1945: to Edmund C. Evans, Mrs. Edmund C. Evans and Ellen Winsor, Caldwell 1948.

Nock A.J., Life liberty and..., [in:] idem, The Disadvantages of Being Educated and Other Essays, Tampa 1996.

Nock A.J., Memoirs of Superfluous Man, New York (1943) 2007.

Nock A.J., On Doing the Right Thing, and Other Essays, New York 1928.

Nock A.J., Our Enemy, The State, New York 1935.

Nock A.J., Selected Letters of Albert Jay Nock, ed. F.J. Nock, Caldwell 1962.

Nock A.J., Snoring as a Fine Art and Twelve Other Essays, Rindge 1958.

Nock A.J., The Book of Journeyman: Essays from the New Freeman, New York (1930) 1967.

Nock A.J., The Disadvantages of Being Educated and Other Essays, Tampa 1996.

Nock A.J., The God's Lookout, [in:] idem, Free Speech and Plain Language, New York 1968.

Nock A.J., The Myth of Guilty Nation, Auburn (1922) 2011.

Nock A.J., The State of The Union. Essays in Social Criticism, Indianapolis 1991.

Nock A.J., The Theory of Education in United States, New York 1932.

Nock A.J., World Scouts, Boston 1912.

Prawo natury w doktrynach polityczno-prawnych Europy, ed. M. Zmierczak, Poznań 2006.

Rau Z., Liberalizm. Zarys myśli politycznej XIX i XX wieku, Warszawa 2000.

Rau Z., Wstęp, [in:] J. Locke, Dwa traktaty o rzadzie, Warszawa 2015.

Rabelais F., The Work of Francis Rabelais, eds. A.J. Nock, C.R. Wilson, New York 1931.

Rothbard M.N., Egalitaryzm jako bunt przeciw ludzkiej naturze, Warszawa 2009.

Rothbard M.N., Etyka wolności, Warszawa 2010.

Rothbard M.N., Manifest libertariański, Warszawa 2014.

Rousseau J.-J., Umowa społeczna, Kęty 2007.

Spencer H., Jednostka wobec państwa, Warszawa 2001.

Strauss L., Prawo naturalne w świetle historii, Warszawa 1969.

Szyszkowska M., Dociekania nad prawem natury, czyli o potrzebach człowieka, Warszawa 1972.

Teluk T., Koncepcje państwa we współczesnym libertarianizmie, Warszawa 2006.

The Freeman Book, ed. B.W. Huebsch, New York 1924.

Thornton R.M., Intoroduction: A Stroll With Albert Jay Nock, [in:] A.J. Nock, The Disadvantages of Being Educated and Other Essays, Tampa 1996.

Tokarczyk R., Klasycy praw natury, Lublin 2009.

Wojtyszyn R., Anty-lewiatan. Doktryna polityczna i prawna Murraya Newtona Rothbarda, Wrocław 2017.

Wreszin M., Albert Jay Nock and the Anarchist Elitist Tradition in Amerika, “American Quarterly" 1969, vol. 21(2/1).

Wreszin M., The Superfluous Anarchist. Albert Jay Nock, Providence 1972. 


\begin{abstract}
ABSTRAKT
Albert Jay Nock (1870-1945) był wybitnym publicystą pierwszej połowy XX w., zaliczanym do pierwszego pokolenia przedstawicieli libertarianizmu. Celem niniejszego artykułu jest odnalezienie odpowiedzi na pytanie: Komu - według Nocka - służy prawo? Kluczowym elementem w przedstawionym wywodzie jest wewnętrzna dychotomia pojęcia prawa, które nie tylko może być postrzegane przez pryzmat paradygmatu pozytywistyczno-prawnego, lecz także stanowi filar koncepcji jusnaturalistycznej. Aby uporządkować przedmiot zakresu badań, posłużono się tezą, według której w doktrynie Nocka istnienie biegunowo odmiennej oceny natury człowieka i jego indywidualnych celów od charakteru funkcjonowania państwa pozwala wykazać dychotomię dwóch przeciwstawnych porządków prawnych, które służą dobru odmiennych podmiotów (jednostki i państwa). W celu usystematyzowania wywodu w pierwszej kolejności przedstawiono koncepcję jednostki i jej relacji z państwem, a następnie omówiono dychotomię rządu i państwa, co finalnie pozwoliło na poddanie analizie relacji zachodzących pomiędzy prawem naturalnym a prawem pozytywnym.
\end{abstract}

Slowa kluczowe: prawo naturalne; prawo pozytywne; libertarianizm; paradygmat pozytywistyczno-prawny; koncepcja jusnaturalistyczna 